\title{
Oral Manifestation COVID-19 and the Rapid Resolution of Symptoms Post-Phtalox Treatment: a Case Series
}

\author{
Manifestación Oral de COVID-19 y la Rápida Resolución de los Síntomas \\ Después del Tratamiento con Phtalox: una Serie de Casos
}

\author{
Bernardo da Fonseca Orcina ${ }^{1} \&$ Paulo Sérgio da Silva Santos ${ }^{1}$
}

ORCINA, B. F. \& SANTOS, P. S. S. Oral manifestation COVID-19 and the rapid resolution of symptoms post-Phtalox treatment: a case series. Int. J. Odontostomat., 15(1):67-70, 2021.

ABSTRACT: The mouth plays a critical role in the transmission of severe acute respiratory syndrome coronavirus 2 (SARS-CoV-2) owing to the fact that both the tongue and salivary glands are conducive environments for the storage and spread of the virus. This case series aimed to describe the oral manifestations of coronavirus disease (COVID-19) and report the rapid response to Phtalox@ treatment in all patients who tested positive for the virus. The patients were grouped based on whether according to convenience as soon as they tested positive for COVID-19. All patients had mouth ulcers and were advised to use $5 \mathrm{~mL}$ of Phtalox $®$ mouthwash for $1 \mathrm{~min}$, five times daily, in addition to standard COVID-19 treatment. Complete healing of mouth ulcers occurred in all patients diagnosed with COVID-19, and the mean duration for complete healing was 2.37 days. General improvement of COVID-19 symptoms was also observed. Based on the rapid recovery of mouth ulcers observed, we suggest that Phtalox $®$ is effective as a complementary oral treatment for ulcers associated with COVID-19.

KEYWORDS: Coronavirus infection, mouth ulcer, mouthwashes, dentistry.

\section{INTRODUCTION}

The mouth is considered as the main source of transmission of infections caused by the severe acute respiratory syndrome coronavirus 2 (SARSCoV-2). The name of the virus refers to its anatomic shape similar to a crown in which outer structures are proteins that facilitate the adherence of SARSCoV-2 to specific human-cell receptors (Meng et al., 2020). The most common receptor facilitating viral entry is angiotensin-converting enzyme II (ACE2), which can be found in high concentrations in our lungs, myocardial and renal cells as well as the oral mucosa, especially in tongue and salivary gland cells (Xu et al., 2020a; Yan et al., 2020).

Although coronavirus disease (COVID-19) is a novel disease, some of its symptoms are well known, including fever, fatigue, myalgia, cough, sore throat, runny nose, sneezes, nausea, vomiting, and diarrhea. In serious cases, other symptoms may be observed, such as pneumonia (with or without hypoxemia), acute breathlessness (SDRA), shock, encephalopathy, myocardial injury, heart failure, coagulation dysfunction, and acute renal lesion (Yuki et al., 2020). In addition, manifestation of the stomatognathic complex is an indicator of SARS-CoV2. Some examples of this manifestation include dysgeusia, ageusia, multiple petechiae, pigmentation on the inserted gum, white spots on the tongue, mouth ulcers found on the tongue, lips and tonsil pillar, and other ulcers that may or may not be directly linked to SARS-CoV-2 (Brandão et al., 2020; Corchuelo \& Ulloa, 2020; Riad et al., 2020).

The main objective of this study was to describe oral manifestations of COVID-19 resembling ordinary mouth ulcers that were found in a group of

\footnotetext{
${ }^{1}$ Department of Surgery, Stomatology, Pathology and Radiology, Bauru School of Dentistry, University of São Paulo, Bauru, São Paulo, Brasil.
} 
patients who tested positive for COVID-19. Further, we aimed to report relevant findings regarding the efficacy of Phtalox® mouthwash, which has antiseptic and virucidal features that are crucial for the treatment of mouth ulcers in COVID-19 patients.

\section{Case series}

This study followed the ethical standards on human experimentation with approved number by the institutional ethics committee from Brazil (CAAE 34070620.6.0000.5417) and patient consent.

A group of 11 patients were assessed for 14 days. All patients tested positive for SARS-CoV-2 using via reverse transcription polymerase chain reaction (RT-PCR) and IgM tests. Four patients presented with mouth ulcers, suggesting a link between mouth ulcers and COVID-19. An assessment of each patient's medical history revealed that none had experienced recurring mouth ulcers or oral or perioral infections caused by herpes simplex. The Phtalox® mouthwash was used to treat patients with signs of COVID-19. The patients used $5 \mathrm{~mL}$ of Phtalox $®$ mouthwash, for 1 minute, five times daily (after getting up, breakfast, lunch, dinner and before bed) for 14 days.

In Case A, a 52-year-old man who had been a smoker for more than 20 years was described. His first symptoms were acute sore throat, a constant cough, and two mouth ulcers located at the back of the buccal groove unilaterally. When the patient first received medical assistance, he was prescribed a computed tomography scan that showed that $25 \%$ of his lungs were affected by acute viral pneumonia. His prescriptions included vitamin D (one tablet per week), azithromycin (one tablet per day for five days), and hydroxychloroquine (one tablet twice a day for 10 days). The patient started using a Phtalox ${ }^{\circledR}$ mouthwash two days after his first symptom occurred. It is important to note that 12 hours after using the mouthwash, mouth ulcers disappeared, and 48 hours after first use of the mouthwash, all the other symptoms disappeared. On the 12th day since the first symptom was reported, the patient tested positive for COVID-19 via an IgG test. However, no further symptoms were reported.

Case B involved a 32-year-old man whose first symptom was pain all over his body, and other normal flu symptoms, including cough and chills. The patient reported the presence of mouth ulcers on his upper lip two days after his first symptom occurred. Use of Phtalox® mouthwash was initiated six days after his first symptom. Three days after using the mouthwash, the patient became asymptomatic and the mouth ulcers disappeared completely. On the 14th day post Phtalox® treatment, the patient tested positive for IgG, and no further symptoms were reported.

Case C involved a 30-year-old woman whose first symptoms were sore throat, pain all over the body, diarrhea, fatigue, cough, and three mouth ulcers on her bottom lip. She was prescribed nitazoxanide, azithromycin, and acetylcysteine. The patient first used Phtalox ${ }^{\circledR}$ mouthwash three days after her first symptoms were reported. Four days after the mouthwash was first used, the patient became asymptomatic and her mouth ulcers disappeared. On the 14th day after her first symptom occurred, the patient tested positive for IgG; however, all of her other symptoms disappeared.

Case D describes a 29-year-old man whose symptoms were sore throat, pain all over his body, fever, cough, anosmia, dysgeusia, and two mouth ulcers on the bottom lip (Fig. 1). The patient was prescribed azithromycin and acetylcysteine. The Phtalox® mouthwash was introduced on the 3rd day after the patient experienced his first symptom. Almost all symptoms disappeared after two days of mouthwash use. However, the patient's senses of taste and smell did not return until four days after he began using the mouthwash. In particular, mouth ulcers disappeared 48 hours post-initiation of Phtalox® treatment. When the patient tested positive (IgG) on the 14th day after his first symptom was reported, no symptoms persisted.

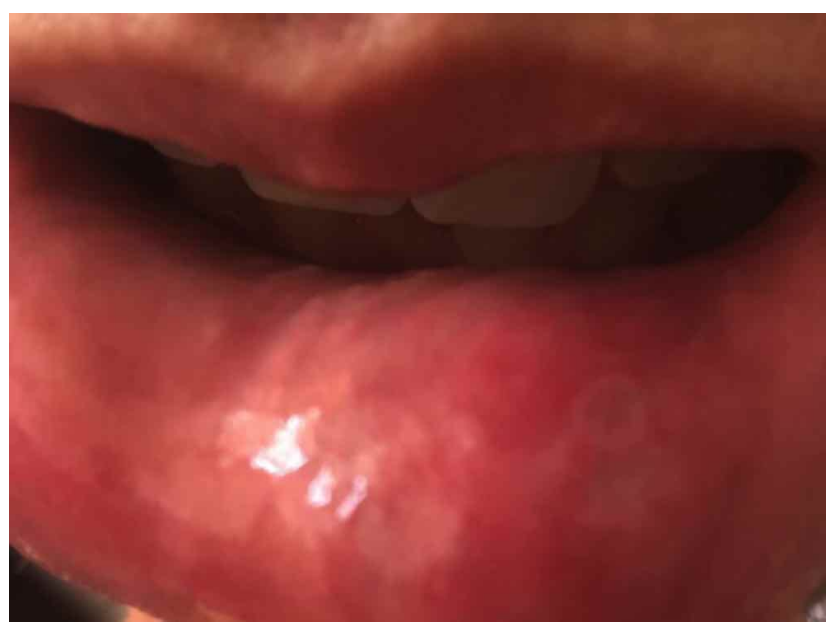

Fig. 1. Image of ulcerations on the lower lip. 
Table. I. Clinical presentation of patients with SARS-CoV-2 who presented with oral manifestation.

\begin{tabular}{lllllllll}
\hline Patient & Sex & $\begin{array}{l}\text { Age } \\
\text { (years) }\end{array}$ & Comorbidities & $\begin{array}{l}\text { Gravity } \\
\text { COVID-19 }\end{array}$ & Oral injury & Location & $\begin{array}{c}\text { Amount } \\
\begin{array}{l}\text { Repair time after } \\
\text { using Phtalox® }\end{array}\end{array}$ \\
\hline 1 & Male & 52 & Smoker & Moderate & Ulcers & Groove bottom & 2 & 12 hours \\
2 & Male & 32 & NA & Light & Ulcers & Lower lip & 1 & 3 days \\
3 & Female & 30 & NA & Light & Ulcers & Lower lip & 3 & 4 days \\
4 & Man & 29 & NA & Light & Ulcers & Lower lip & 2 & 2 days
\end{tabular}

\section{DISCUSSION}

All patients observed in these clinical cases were diagnosed with mild or moderate COVID-19, according to the literature (Pan American Health Organization, 2020; Nuno-Gonzalez et al., 2020). It is important to note that none of the patients required hospital admittance, which suggests a bias against oral manifestations of COVID-19. It is common knowledge that some of infected patients do not have their mouth checked when they seek medical assistance due to the associated risk of contamination to healthcare workers. It is possible that some oral manifestations of the disease may could be caused by hospital treatment including the use of masks, ventilation, and orotracheal intubation, rather than COVID-19 itself (Nuno-Gonzalez et al.).

In contrast, the presence of ACE2 in cells of the oral mucosa, especially the tongue, indicates that the mouth is a likely infection route for SARS-CoV-2 (Xu et al., 2020a). Furthermore, our salivary glands are capable of maintaining viral viability, since it is constantly secreted into the mouth (Xu et al., 2020b). Therefore, SARS-CoV-2 contacts the oral mucosa, suggesting a link between viral infection and the manifestation of mouth ulcers. There has been some evidence reported in the literature that suggests a relationship between mouth ulcers healing and overall infection improvement, even though samples extracted from lesions have not yet been examined to confirm the presence of the virus (Brandão et al.).

To date, viral load has been used as an indicator of COVID-19 disease severity. The average viral load observed cases of enhanced severity has been reported to be 60 times greater than that of mild cases, and viral load has been associated with increased risk of intubation and death (Liu et al., 2020; Magleby et al., 2020). Although the viral load of mouth ulcers has not been clinically tested, it was observed that mouth ulcer severity was positively associated with disease severity (Brandão et al.).
In all cases, the use of the PHTALOX $®$ mouthwash improved not only the general health of the patients but also contributed to the rapid healing of mouth ulcers (Table I). Improved general health due to Phtalox® mouthwash use was also reported in a different study, which examined eight patients who tested positive for COVID-19. For all patients, symptoms of infection disappeared and mouth ulcers improved rapidly after a single use of Phtalox $®$ mouthwash. Phtalox $®$ is an antiseptic mouthwash that contains phtalocyanine, which activates the continuous production of reactive oxygen when in contact with molecular oxygen. In vitro tests assessing the mouthwash revealed its antimicrobial and antiviral characteristics (against respiratory viruses), and its low degree of toxicity (Santos et al., 2020; Teodoro et al., 2020).

In a different study involving 26 patients who tested positive for SARS-CoV-2, it was observed that mouth ulcers found on their tongues, which were treated with paracetamol and chlorhexidine, took on average 8.35 days to disappear. However, the patients in the same study whose mouth ulcers were treated with Phtalox® mouthwash took an average of 2.37 days to resolve (Riad et al.). Viral diseases found in the mouth affect the oral tissues, which contributes to the formation of mouth ulcers in the shape of single or multiple blisters. This occurs due to cellular damage that results from reduced immunity caused by viral proteins (Santosh \& Muddana, 2020). Generally speaking, viral oral infections can trigger the formation of mouth ulcers in the oral mucosa, and these ulcers have been identified as a common symptom of viral infection (Clarkson et al., 2017). Taken together, previous data and findings of the four clinical cases reported suggest that Phtalox $®$ mouthwash has virucidal healing properties and is also likely to have antiinflammatory activity. Undoubtedly, more studies are needed to identify the pathophysiology of the mouth ulcers found in patients that test positive for SARSCoV-2 as well as to test further assess the antiviral effect of Phtalox®. 
In conclusion, the clear connection between the rapid healing of mouth ulcers and general health improvement in patients suggests the therapeutic effect of Phtalox ${ }^{\circledR}$ mouthwash when treating oral manifestations caused by SARS-CoV- 2 .

\section{ACKNOWLEDGMENTS}

This study was financed in part by the Coordenação de Aperfeiçoamento de Pessoal de Nível Superior (CAPES), Brazil (Finance Code 001), and TRIALS-Oral Health \& Technologies.

ORCINA, B. F. \& SANTOS, P. S. S. Manifestación oral de COVID-19 y la rápida resolución de los síntomas después del tratamiento con Phtalox: una serie de casos. Int. J. Odontostomat., 15(1):67-70, 2021.

RESUMEN: La cavidad oral juega un papel fundamental en la transmisión del síndrome respiratorio agudo severo coronavirus 2 (SARS-CoV-2) debido al hecho de que tanto la lengua como las glándulas salivales son entornos propicios para el almacenamiento y la propagación del virus. Esta serie de casos tuvo como objetivo describir las manifestaciones orales de la enfermedad por coronavirus (COVID-19) e informar la rápida respuesta al tratamiento con Phtalox ${ }^{\circledR}$ en todos los pacientes que dieron positivo al virus. Los pacientes se agruparon en función de su conveniencia tan pronto como dieron positivo a COVID-19. Todos los pacientes tenían úlceras en la boca y se les recomendó utilizar $5 \mathrm{ml}$ de enjuague oral Phtalox® durante 1 minuto, cinco veces al día, además del tratamiento estándar de COVID-19. La curación completa de las úlceras orales ocurrió en todos los pacientes diagnosticados con COVID-19, y la duración media para la curación completa fue de 2,37 días. También se observó una mejoría general de los síntomas de COVID-19. Con base en la rápida recuperación de las úlceras orales observadas, sugerimos que Phtalox® es eficaz como tratamiento oral complementario para las úlceras asociadas con COVID-19.

KEYWORDS: Infección por coronavirus, úlcera oral, enjuagues orales, odontología.

\section{REFERENCES}

Brandão, T. B.; Gueiros, L. A.; Melo, T. S.; Prado-Ribeiro, A. C.; Nesrallah, A. C. F. A.; Prado, G. V. B.; Santos-Silva, A. R. \& Migliorati, C. Oral lesions in patients with SARS-CoV-2 infection: could the oral cavity be a target organ? Oral Surg. Oral Med. Oral Pathol. Oral Radiol., 2020. DOI: https://www.doi.org/10.1016/j.000o.2020.07.014

Clarkson, E.; Mashkoor, F. \& Abdulateef, S. Oral viral infections: diagnosis and management. Dent. Clin. North Am., 61(2):351-63, 2017.

Corchuelo, J. \& Ulloa, F. C. Oral manifestations in a patient with a history of asymptomatic COVID-19: Case report. Int. J. Infect. Dis., 100:154$7,2020$.
Liu, Y.; Yan, L. M.; Wan, L.; Xiang, T. X.; Le, A.; Liu, J. M.; Peiris, M.; Poon, L. L. M. \& Zhang, W. Viral dynamics in mild and severe cases of COVID-19. Lancet Infect. Dis., 20(6):656-7, 2020.

Magleby, R.; Westblade, L. F.; Trzebucki, A.; Simon, M. S.; Rajan, M.; Park, J.; Goyal, P.; Safford, M. M. \& Satlin, M. J. Impact of SARSCoV-2 viral load on risk of intubation and mortality among hospitalized patients with Coronavirus Disease 2019. Clin. Infect. Dis., ciaa851, 2020.

Meng, L.; Hua, F. \& Bian, Z. Coronavirus disease 2019 (COVID-19): emerging and future challenges for dental and oral medicine. J. Dent. Res., 99(5):481-7, 2020.

Nuno-Gonzalez, A.; Martin-Carrillo.; Magaletsky, K.; Martin Rios, M. D.; Herranz Mañas, H.; Artigas Almazan, J.; García Casasola, G.; Perez Castro, E.; Gallego Arenas, A.; Mayor Ibarguren, A.; et al. Prevalence of mucocutaneous manifestations in 666 patients with COVID-19 in a field hospital in Spain: oral and palmoplantar findings. Br. J. Dermatol., 2020. DOI: https://www.doi.org/10.1111/bjd.19564, 2020.

Pan American Health Organization (PAHO/WHO). Manejo Clínico da Covid-19. 27 de maio de 2020. Washington (DC), Pan American Health Organization, 2020. Available from: https://www.paho.org/ $\mathrm{pt} /$ taxonomy/term/13

Riad, A.; Kassem, I.; Hockova, B.; Badrah, M. \& Klugar, M. Tongue ulcers associated with SARS-CoV-2 infection: A case series. Oral Dis., 2020. DOI: https://www.doi.org/10.1111/odi.13635

Santos, C.; Novaes, P.; Farias, M.; Khouri, S.; Vilhena, F. \& Teodoro, G. Antibiofilm Action of PHTALOX®-containing Oral Care Formulations, J. Dent. Res., 99(Spec. Iss A):abstract number, 3326, 2020.

Santosh, A. B. R. \& Muddana, K. Viral infections of oral cavity. J. Family Med. Prim. Care, 9(1):36-42, 2020.

Teodoro, G.; Santos, C.; Carvalho, M.; Koga-Ito, C.; Khouri, S. \& Vilhena, F. PHTALOX® Antimicrobial Action and Cytotoxicity: in vitro Study. J. Dent. Res., 99(Spec. Iss. A):abstract number, 0839, 2020.

Xu, H.; Zhong, L.; Deng, J.; Peng, J.; Dan, H.; Zeng, X.; Li, T. \& Chen, Q. High expression of ACE2 receptor of 2019-nCoV on the epithelial cells of oral mucosa. Int. J. Oral Sci., 12:8, 2020a.

Xu, J.; Li, Y.; Gan, F.; Du, Y. \& Yao, Y. Salivary glands: potential reservoirs for COVID-19 asymptomatic infection. J. Dent. Res., 99(8):989, 2020b.

Yan, R.; Zhang, Y.; Li, Y.; Xia, L.; Guo Y. \& Zhou, Q. Structural basis for the recognition of SARS-CoV-2 by full-length human ACE2. Science, 367(6485):1444-8, 2020.

Yuki, K.; Fujiogi, M. \& Koutsogiannaki, S. COVID-19 pathophysiology: A review. Clin. Immunol., 215:108427, 2020.

Corresponding author:

Paulo Sérgio da Silva Santos, DDS, PhD

Associate Professor

Department of Surgery, Stomatology, Pathology and

Radiology

Bauru School of Dentistry

University of São Paulo

Al. Dr. Octávio Pinheiro Brisolla, 9-75,

CEP (ZIP CODE) 17012-901

Bauru - São Paulo

BRAZIL

E-mail: paulosss@fob.usp.br 